\title{
PENERAPAN METODE PENEMUAN TERBIMBING DALAM PEMBELAJARAN MATEMATIKA DI SMA NEGERI 2 PADANG
}

\author{
Christina Khaidir \\ Program Studi Tadris Matematika, Jurusan Tarbiyah STAIN Batusangkar \\ Korespondensi: Jln. Sudirman No. 137 Kubu Rajo, Lima Kaum Barusangkar, Sumatera Barat
}

\begin{abstract}
Teachers' domination in teaching Mathematics is one of many factors why students disliked to study it. To solve this problem, a good method has to be promoted in order to improve students' motivation and their ability in Mathematics. This research was an experimental research through Guide Discovery Method. The subject of the research was the eleventh grade students of Physical Science (IPA) of SMAN 2 Padang who were registered in 2007/2008 academic year. The research result showed that there was different abilities between the students after getting treatment in which the students who were taught through Guide Discovery Method had good abilities rather than the students who were taugh conventionally.
\end{abstract}

Kata kunci: Metode Penemuan Terbimbing, Pembelajaran Matematika

\section{PENDAHULUAN}

$\mathrm{D}$ alam kurikulum matematika 2004 dikemukakan bahwa tujuan umum pendidikan matematika ditekankan pada siswa untuk memiliki: (1) kemampuan yang berkaitan dengan matematika yang dapat digunakan dalam memecahkan masalah matematika, pelajaran lain, ataupun berkaitan dengan kehidupan nyata, (2) kemampuan menggunakan matematika sebagai alat komunikasi, dan (3) kemampuan menggunakan matematika sebagai cara bernalar yang dapat dialih gunakan pada setiap keadaan, seperti berpikir kritis, berpikir sistematis, bersifat objektif, bersifat jujur, bersifat disiplin dalam memandang dan menyelesaikan masalah. Akan tetapi pada kenyataannya di lapangan, banyak kekecewaan dengan hasil yang dicapai siswa. Sangat sedikit siswa yang mempunyai kecenderungan untuk mempelajari dan memahami matematika dengan baik, keadaan tersebut membuat siswa tidak memperoleh hasil yang maksimal dalam pencapaian hasil belajar.

Berdasarkan pengamatan peneliti di lapangan terlihat bahwa dalam proses pembelajaran matematika di SMA Negeri 2 Padang, guru lebih dominan menggunakan metode ceramah, di mana guru mengajar secara otokratik kepada siswa, sementara siswa mendengarkan secara pasif, sehingga tidak terjadi interaksi yang positif antara guru dan siswa dan juga antar siswa. Sebagai tenaga pengajar, guru perlu memikirkan pengembangan sistem pembelajaran yang lebih baik, dengan penekanan pada keterlibatan siswa secara langsung dalam proses belajar yang berorientasi pada kegiatan yang bersifat aktivitas. Ceramah 
yang panjang dan berlebihan membosankan siswa, sehingga tingkat kognitif yang lebih tinggi (aplikasi, analisis, sintesis dan evaluasi) jarang dikuasai siswa, karena mereka tidak bekerja secara aktif dengan informasi yang disampaikan. Penekanan dalam proses pembelajaran seperti ini terletak pada kegiatan mengajar, bukan kepada kegiatan belajar. Dengan demikian peneliti melihat bahwa pembelajaran matematika, metode mengajar yang digunakan guru perlu mendapat perhatian.

Guru sebagai penanggung jawab utama dalam kegiatan belajar mengajar harus dapat memilih metode mengajar yang dapat menciptakan suasana belajar yang dapat menyenangkan bagi siswa. Sesuai dengan pendapat Ruseffendi (1991) bahwa "Salah satu kemampuan yang harus dimiliki guru matematika agar menjadi guru profesional adalah mampu mendemonstrasikan dan menerapkan macam-macam metode, dan teknik mengajar dalam bidang studi yang diajarkan". Seorang guru harus dapat memilih strategi atau metode dalam pelaksanaan proses pembelajaran sehingga lebih banyak melibatkan siswa secara aktif dalam belajar baik aktif secara mental, aktif secara fisik, maupun sosial, bersemangat gembira dan senang belajar matematika. Sebagaimana yang dikatakan oleh Herman Hudojo (1998) "Strategi pembelajaran yang jitu dalam menghadapi masa depan yang serba tidak menentu adalah membelajarkan siswa dengan melibatkan siswa secara maksimum". Untuk mengatasi hal yang demikian maka dituntut kemampuan guru dalam memilih dan menggunakan metode mengajar yang tepat sehingga dapat meningkatkan hasil belajar siswa. Salah satu metode yang dapat digunakan adalah metode penemuan terbimbing. Metode penemuan terbimbing adalah suatu metode mengajar yang menekankan pembelajaran lebih berpusat kepada siswa. Peranan guru dalam metode ini adalah sebagai fasilisator dan motivator.

Dengan metode penemuan terbimbing siswa bukan hanya diharapkan mendapatkan hal yang baru, tetapi dalam lebih memahami konsep yang dipelajarinya dan dapat mengingatnya lebih lama. Jadi konsep yang dipelajarinya akan bertahan lama jika didapatkan dengan melakukannya sendiri. Dalam metode penemuan terbimbing guru perlu menjelaskan bagaimana hubungan suatu konsep yang sedang dipelajari dengan konsep lain. Kemampuan mengkaitkan antar konsep matematika siswa dalam metode penemuan terbimbing ini sangat dibutuhkan untuk dapat menemukan sendiri. Jika siswa dapat memahami konsep dengan baik maka hasil belajar siswa tersebut akan meningkat pula.

\section{PERUMUSAN MASALAH}

Dalam penelitian ini dirumuskan permasalahan sebagai berikut.

1. Apakah hasil belajar matematika siswa yang diajar dengan menggunakan metode penemuan terbimbing dengan setting kooperatif lebih tinggi dari pada yang diajar dengan menggunakan metode konvensional?

2. Apakah hasil belajar matematika siswa dengan kemampuan awal matematika tinggi yang diajar dengan metode penemuan terbimbing dengan setting kooperatif lebih tinggi dari pada yang diajar dengan metode konvensional?

3. Apakah hasil belajar matematika siswa dengan kemampuan awal matematika rendah yang diajar dengan metode penemuan terbimbing dengan setting kooperatif lebih tinggi dari pada yang diajar dengan metode konvensional?

4. Apakah ada interaksi antara metode pembelajaran dan tingkat kemampuan awal matematika siswa dalam mempengaruhi hasil belajar siswa? 


\section{TUJUAN PENELITIAN}

melihat:

Penelitian ini bertujuan untuk

1. Perbedaan hasil belajar matematika siswa yang diajar dengan menggunakan metode penemuan terbimbing dengan setting kooperatif dan yang diajar dengan menggunakan metode konvensional.

2. Perbedaan hasil belajar matematika siswa dengan kemampuan awal matematika tinggi yang diajar dengan metode penemuan terbimbing dengan setting kooperatif dan yang diajar dengan metode konvensional.

3. Perbedaan hasil belajar matematika siswa dengan kemampuan awal matematika rendah yang diajar dengan metode penemuan terbimbing dengan setting kooperatif dan yang diajar dengan metode konvensional.

4. Adanya interaksi antara metode pembelajaran dan tingkat kemampuan awal matematika siswa dalam mempengaruhi hasil belajar matematika.

\section{KAJIAN TEORI}

\section{Pembelajaran Matematika}

Dalam hubungannya dengan matematika, Muliyardi (2003) mengemukakan bahwa: Pembelajaran matematika adalah upaya untuk membantu siswa untuk mengkonstruksi konsepkonsep atau prinsip-prinsip matematika dengan kemampuannya sendiri melalui proses internalisasi sehingga konsep dan prinsip itu terbangun kembali.

Dalam pembelajaran matematika sangat diperlukan sekali peranan aktif siswa, peranan aktif siswa ini dalam menghubungkan konsep-konsep dan struktur dari matematika yang dipelajarinya.

Dalam pembelajaran matematika pengalaman belajar masa lampau memegang peranan untuk memahami konsep-konsep. Dengan demikian siswa diharapkan belajar aktif dan tidak sekedar menerima saja yang diberikan guru. Siswa yang aktif akan melibatkan dirinya dalam menemukan prinsip dasar sehingga siswa lebih mengerti konsep dengan baik dan mengingat lebih lama serta dapat menggunakan konsep-konsep tersebut.

Guru sebagai salah satu faktor penting dalam proses belajar harus bisa menentukan hal-hal apa saja yang dapat mendorong keberhasilan siswa dalam belajar matematika. Ia juga harus mampu memberikan motivasi belajar dan membuat strategi pembelajaran matematika yang tepat untuk menumbuhkan semangat dan minat siswa dalam belajar matematika.

\section{Metode Penemuan Terbimbing}

Metode penemuan adalah salah satu metode pembelajaran yang dapat digunakan sebagai strategi untuk mencetak siswa yang tidak hanya pandai menghafal tetapi materi pelajaran yang diterimanya dapat dipahaminya. Menurut Herman Hudojo (1988), "Metode penemuan merupakan suatu cara untuk menyampaikan ide atau gagasan lewat proses menemukan". Siswa menemukan sendiri pola-pola dan struktur matematika melalui sederetan pengalaman belajar yang lampau. Seiring dengan pendapat tersebut Ruseffendi (1988) mengemukakan bahwa: Metode penemuan adalah metode mengajar yang mengatur pengajaran sedemikian rupa sehingga anak memperoleh pengetahuan yang sebelumnya belum diketahuinya tidak melalui proses pemberitahuan, sebagian atau seluruhnya ditemukan sendiri.

Dengan pembelajaran menggunakan metode penemuan diharapkan siswa benar-benar aktif dalam belajar, menemukan sendiri konsep dan prinsip yang dipelajarinya. Keberhasilan pembelajaran dengan metode penemuan sangat tergantung pada kemampuan siswa. Kemampuan siswa dalam artian 
kemampuan yang telah dimiliki siswa sebelumnya. Pelaksanaannya harus disesuaikan dengan pengetahuan yang telah diperoleh sebelumnya. Memang tidak semua pelajaran dapat disajikan dengan metode penemuan.

Berdasarkan pendapat-pendapat di atas, metode penemuan terbimbing dalam pembelajaran matematika adalah suatu model pembelajaran yang menghendaki siswa menemukan ide-ide misalnya: aturan, pola, hubungan atau cara menyelesaikan suatu masalah melalui keterlibatannya secara aktif dalam pembelajaran yang didasarkan pada serentetan pengalaman-pengalaman belajar yang lampau. Keterlibatan secara aktif dapat berupa kegiatan mengadakan percobaan atau penemuan sebelum membuat kesimpulan, atau memanipulasi, membuat struktur, dan mentransfer informasi sehingga menemukan informasi baru yang berupa kebenaran matematika.

\section{KERANGKA BERPIKIR}

Dalam pembahasan kerangka berpikir, akan diuraikan kerangka pemikiran tentang penelitian yang didasarkan pada tujuan penelitian.

1. Perbedaan hasil belajar matematika siswa yang diajar dengan menggunakan metode penenmuan terbimbing dengan hasil belajar matematika siswa yang diajar dengan menggunakan metode konvensional.

Proses pembelajaran yang menggunakan metode penemuan terbimbing bersifat student centered. Dengan kata lain proses pembelajaran akan lebih efektif apabila siswa terlibat dalam menggunakan proses mentalnya untuk menemukan beberapa konsep atau prinsip. Proses mental tersebut misalnya: mengamati, menggolong-golongkan, membuat dugaan, menjelaskan, mengukur, membuat kesimpulan dan sebagainya.
Pengkonstruksian pengetahuan dilakukan melalui kegiatan penemuan pengetahuan baru yang dikaitkan dengan pengetahuan awal yang telah dimilikinya. Selain itu kegiatan penemuan juga dapat dilakukan melalui bertanya, berdiskusi dan berbagi pengalaman dengan teman atau melakukan kegiatan yang telah dimodelkan oleg guru atau siswa yang lain.

Metode penemuan bertujuan untuk membiasakan siswa melakukan keterampilan proses dalam menemukan ilmu pengetahuan. Dalam penggunaan dan penerapan metode penemuan ini, maka siswa akan lebih mampu mengembangkan dan mengaplikasikan ilmu yang telah diperoleh dan menggunakan potensi sumber belajar yang ada disekelilingnya, karena dalam proses belajar siswa diharapkan lebih kritis dan kreatif sehingga tidak hanya menerima materi dari guru yang mengajar, tetapi dapat mencari sumber lain yang dapat menambah wawasan siswa sehingga siswa dapat menemukan prinsip dan konsep dari proses belajar itu sendiri.

2. Perbedaan hasil belajar siswa yang memiliki kemampuan awal (tinggi/ rendah) diajar dengan metode penemuan terbimbing dan metode konvensional.

Pelajaran matematika merupakan mata pelajaran penting yang selalu digunakan oleh mata pelajaran lain terutama bidang sains. Kemampuan awal matematika siswa, misalnya kemampuan dasar dalam mengoperasikan bilangan merupakan faktor penentu keberhasilan siswa. Siswa yang berkemampuan awal tinggi akan membantu siswa mengembangkan, memperbanyak kesiapan serta penguasaan keterampilan dalam proses kognitif atau pengenalan siswa. Sehingga pembentukan pengetahuan, jangka panjang siswa 
dapat dilakukan sekaligus meningkatkan hasil belajarnya. Sedangkan siswa yang berkemampuan awal rendah biasanya kurang cepat merespon informasi yang datang, sementara informasi selama pembelajaran berlangsung akan terus bergulir sesuai dengan batas kurikulum yang ditentukan. Akhirnya informasi itu banyak berlalu tanpa penguasaan yang baik oleh siswa.

3. Interaksi antara metode pembelajaran dengan kemampuan awal siswa.

Metode penemuan terbimbing berorientasi pada proses pembelajaran yang berpusat pada siswa. Dengan diterapkan metode penemuan terbimbing secara kooperatif berdasarkan kemampuan awal yang dimiliki siswa, maka dalam hal ini siswa dituntut untuk lebih aktif dalam belajar dan dapat menemukan sendiri hubungan antara konsep-konsep dan siswa mendapat kesempatan untuk be-rinteraksi satu sama lain. Interaksi yang terjadi antar siswa dalam pembelajaran akan dapat menciptakan suasana belajar yang mnyenangkan dan dinamis sehingga siswa semakin termotivasi untuk belajar, yang pada akhirnya akan berpengaruh terhadap hasil belajar siswa. Dalam pelaksanaannya siswa diharapkan dapat bekerja sama dengan kelompok untuk melakukan penemuan. Berdasarkan hal di atas ada interaksi yang positif antara penggunaan metode pembelajaran dengan kemampuan awal siswa.

\section{HIPOTESIS PENELITIAN}

1. Hasil belajar matematika kelompok siswa yang diajar dengan menggunakan metode penemuan terbimbing lebih tinggi dari hasil belajar kelompok siswa yang diajar dengan menggunakan metode konvensional.
1. Hasil belajar matematika kelompok siswa yang kemampuan awal tinggi yang diajar dengan metode penemuan terbimbing lebih tinggi dari pada yang diajar dengan metode konvensional.

2. Hasil belajar matematika kelompok siswa yang kemampuan awal rendah yang diajar dengan metode penemuan terbimbing lebih tinggi dari pada yang diajar dengan metode konvensional.

3. Terdapat interaksi antara metode pembelajaran dan tingkat kemampuan awal matematika siswa dalam mempengaruhi hasil belajar matematika siswa.

\section{METODOLOGI PENELITIAN}

Penelitian ini termasuk dalam jenis eksperimen. Suharsimi Arikunto (2003b) menyatakan bahwa "penelitian eksperimen merupakan penelitian yang dimaksudkan untuk mengetahui ada tidaknya akibat dari 'sesuatu' yang dikenakan pada subjek selidik". Dengan perkataan lain penelitian eksperimen mencoba untuk meneliti ada tidaknya perbedaan akibat treatmen yang diberikan dengan cara membandingkan satua atau lebih kelompok eksperimen yang diberi perlakuan dengan satu atau lebih kelompok yang tidak menerima perlakuan sebagai kontrol untuk perbandingan.

Populasi penelitian ini adalah semua siswa kelas XI IPA SMA Negeri 2 Padang yang terdiri dari 6 kelas. Sampel dalam penelitian ini terdiri dari dua kelompok yaitu kelompok eksperimen dan kelompok kontrol. Penentuan kelas untuk sampel tersebut dilakukan dengan undian. Kelas yang terpilih pada undian pertama dipergunakan sebagai kelompok eksperimen dan diberikan perlakuan dengan metode penemuan terbimbing, sedangkan kelas yang terpilih pada undian kedua merupakan kelompok kontrol yang menggunakan 
metode konvensional. Penentuan sampel yang mewakili kelompok siswa yang berkemampuan awal tinggi dan rendah dilakukan tes awal, setelah dikelompokkan dari nilai yang tertingggi sampai nilai terendah kemudian diambil $27 \%$ dari masing-masing kelompok sebagai sampel penelitian (Suharsimi Arikunto, 2003b).

\section{DEFINISI OPERASIONAL}

\section{Variabel Penelitian}

Variabel bebas dalam penelitian ini adalah metode pembelajaran yang terdiri dari dua taraf, yaitu metode penemuan terbimbing dan metode konvensional. Metode penemuan terbimbing adalah suatu cara menyampaikan ide atau gagasan kepada siswa lewat proses menemukan. Dengan bimbingan guru, siswa menemukan pola-pola dan struktur matematika melalui sederetan pengalaman belajar yang dikaitkan dengan kehidupan sehari-hari. Guru bertindak sebagai fasilisator, motivator, dan evaluator dalam proses penemuan. Variabel bebas kedua adalah metode konvensional yaitu metode mengajar di mana guru menjelaskan atau menerangkan materi pelajaran secara klasikal dan memberikan beberapa contoh yang dilanjutkan dengan pemberian tugas untuk dikerjakan di sekolah atau di rumah. Variabel moderator adalah kemampuan awal yang terdiri dari dua taraf yaitu kemampuan awal tinggi dan kemampuan awal rendah. Kemampuan awal adalah kemampuan yang dimiliki siswa sebelum proses pembelajaran yang merupakan pengetahuan prasyarat untuk mempelajari materi pelajaran berikutnya. Sedangkan variabel terikat adalah hasil belajar siswa. Hasil belajar diartikan sebagai skor yang diperoleh siswa dari tes yang dilakukan setelah pelaksanaan perlakuan penelitian. Tes dilaksanakan secara tertulis berupa tes bentuk uraian.

\section{Rancangan Penelitian}

Prosedur pelaksanaan penelitian adalah sebagai berikut:

1) Perancangan Perangkat Pembelajaran

a) Perangkat pembelajaran yaitu rencana pelaksanaan pembelajaran (RPP) dan LKS serta lembaran tes hasil belajar yang dirancang oleh peneliti dengan mengacu pada teori-teori yang ada.

b) Rencana pelaksanaan pembelajaran, LKS dan lembaran hasil belajar divalidasi melalui validator.

c) Hasil validasi didiskusikan dan disesuaikan untuk perubahan sehingga menjadi perangkat yang valid dan siap untuk diterapkan.

d) Penyediaan alat dan bahan pendukung penelitian lainnya.

2) Pelaksanaan Penelitian

a) Pra eksperimen

Penerapan suatu metode pembelajaran pada kelas eksperimen memungkinkan terjadinya perubahan bentuk dan pola pembelajaran dilakukan guru yang mengajar di kelas itu sebelumnya. Untuk itu diperlukan kondisi penyesuaian atau pembiasaan terhadap metode pembelajaran yang akan diterapkan untuk guru maupun siswa. Kegiatan ini dilakukan dengan cara penerapan metode pembelajaran yang akan diterapkan pada materi sebelum materi perlakuan.

b) Pelaksanaan kegiatan eksperimen Kegiatan eksperimen dilakukan dengan menerapkan metode penemuan terbimbing pada kelas sampel yang telah ditentukan. Jadwal pelaksanaan eksperimen untuk masing-masing kelas sampel sesuai dengan jadwal yang telah 
disusun sekolah, dan tidak mengganggu program yang telah disusun. Observasi kelas dilakukan oleh observer dari teman sejawat dengan tujuan untuk melihat aktivitas siswa sesuai dengan metode yang diterapkan dengan menggunakan lembar observasi yang telah disediakan.

c) Melakukan tes hasil belajar Tes hasil belajar dilakukan serentak untuk kedua kelas sampel dengan melibatkan teman sejawat dalam pelaksanaannya.

\section{TEKNIK ANALISA DATA}

Analisis data bertujuan untuk melihat perbedaan rata-rata skor hasil tes antara kelas eksperimen dan kelas kontrol signifikan atau tidak. Dalam menganalisis data ini penulis melakukan langkah-langkah yang diuraikan di bawah ini.

1. Uji Normalitas

2. Uji Homogenitas Variansi

3. Uji Kesamaan Rata-rata

Dalam hal ini hipotesis statistiknya yaitu:

$$
\begin{aligned}
& \mathrm{H}_{0}: \mu_{1}=\mu_{2} \\
& \mathrm{H}_{1}: \mu_{1}>\mu_{2}
\end{aligned}
$$

Dengan $\mu_{1}$ dan $\mu_{2}$ masing-masing adalah rata-rata hasil belajar matematika siswa kelompok eksperimen dan kontrol. Untuk menguji hipotesis di atas ada tiga alternatif uji-t student yang mungkin digunakan yang dikemukakan oleh Sudjana (2002) yaitu:

a. Jika skor hasil belajar berdistribusi normal dan variansi populasi homogen maka untuk uji kesamaan rata-rata digunakan rumus:

$$
\begin{gathered}
t=\frac{\overline{X_{1}}-\overline{X_{2}}}{S \sqrt{\frac{1}{n_{1}}+\frac{1}{n_{2}}}} \quad \text { dengan: } \\
S=\sqrt{\frac{\left(n_{1}-1\right) S_{1}^{2}+\left(n_{2}-1\right) S_{2}^{2}}{n_{1}+n_{2}-2}}
\end{gathered}
$$

Keterangan:

$\overline{X_{1}} \quad=$ Skor rata-rata kelas eksperimen

$\overline{X_{2}} \quad=$ Skor rata-rata kelas kontrol

$\mathrm{n}_{1}=$ Jumlah siswa kelas eksperimen

$\mathrm{n}_{2}=$ Jumlah siswa kelas

kontrol

$\mathrm{S}_{1}=$ Simpangan baku

kelas eksperimen

$\mathrm{S}_{2} \quad=$ Simpangan baku

kelas kontrol

$\mathrm{S}=$ Simpangan baku gabungan

Kriteria pengujiannya adalah terima $\mathrm{H}_{0}$ jika $\mathrm{t}_{\text {hitung }}<\mathrm{t}_{\text {tabel }}$ dengan $\mathrm{dk}=\mathrm{n}_{1}+\mathrm{n}_{2}-2$, selain itu $\mathrm{H}_{0}$ ditolak.

b. Jika populasi berdistribusi normal dan variansinya tidak homogen maka dipakai rumus $t$ berikut:

$$
t^{\prime}=\frac{\overline{X_{1}}-\overline{X_{2}}}{\sqrt{\left(\frac{S_{1}^{2}}{n_{1}}\right)+\left(\frac{S_{2}^{2}}{n_{2}}\right)}}
$$

Kriteria pengujiannya adalah tolak $\mathrm{H}_{0}$ jika

$$
\mathbf{t}^{\prime} \geq \frac{w_{1} t_{1}+w_{2} t_{2}}{w_{1}+w_{2}}, \text { dan terima }
$$

$\mathrm{H}_{0}$ dalam hal lainnya. 


\section{HASIL PENELITIAN}

\section{Analisis Uji Hipotesis}

a. Uji Normalitas

Tabel: Hasil Uji Normalitas Data Hasil Belajar

\begin{tabular}{ccc}
\hline $\begin{array}{c}\text { Nilai } \\
(\mathbf{L})\end{array}$ & $\mathbf{B}_{\mathbf{1}}$ & $\mathbf{B}_{\mathbf{2}}$ \\
\hline $\begin{array}{c}\mathrm{L} \\
\text { hitung }\end{array}$ & 0,0757 & 0,0848 \\
\hline L tabel & 0,1367 & 0,1419 \\
\hline
\end{tabular}

Keterangan:

$\mathrm{B}_{1}=$ Metode Penemuan Terbimbing dengan Setting Kooperatif

$\mathrm{B}_{2}=$ Metode Konvensional

Berdasarkan perhitungan uji normalitas diperoleh pada kelas eksperimen $\mathrm{L}$ hitung $=0,0757$ dan $\mathrm{L}$ tabel $=$ 0,1367. Jadi L hitung < L tabel, maka dapat disimpulkan data berdistribusi normal. Demikian juga pada kelas kontrol L hitung $=0,0848$ dan $\mathrm{L}$ tabel $=0,1419$. Jadi L hitung < L tabel, maka dapat disimpulkan data berdistribusi normal.

Tabel: Hasil Uji Normalitas Data Hasil Belajar Kelompok Metode Pembelajaran dengan kemampuan Awal Tinggi

\begin{tabular}{ccc}
\hline $\begin{array}{c}\text { Nilai } \\
(\mathbf{L})\end{array}$ & $\mathbf{A}_{1} \mathbf{B}_{1}$ & $\mathbf{A}_{2} \mathbf{B}_{2}$ \\
\hline $\begin{array}{c}\mathrm{L} \\
\text { hitung }\end{array}$ & 0,1513 & 0,0993 \\
\hline L tabel & 0,2420 & 0,2420 \\
\hline
\end{tabular}

Keterangan:

$\mathrm{A}_{1} \mathrm{~B}_{1}=$ Metode Penemuan Terbimbing dengan Setting Kooperatif dengan Kemampuan Awal Tinggi

$\mathrm{A}_{2} \mathrm{~B}_{2}=$ Metode Konvensional dengan KemampuanAwal Tinggi Berdasarkan perhitungan uji normalitas diperoleh pada kelas eksperimen L hitung $=$ 0,1513 dan $\mathrm{L}$ tabel $=0,2420$. Jadi L hitung < L tabel, maka dapat disimpulkan data berdistribusi normal. Demikian juga pada kelas kontrol $\mathrm{L}$ hitung $=0,0993$ dan $\mathrm{L}$ tabel $=0,2420$. Jadi L hitung $<$ L tabel, maka dapat disimpulkan data berdistribusi normal.

Tabel: Hasil Uji Normalitas Data Hasil Belajar Kelompok Metode Pembelajaran dengan kemampuan Awal Rendah

\begin{tabular}{ccc}
\hline Nilai (L) & $\mathbf{A}_{\mathbf{1}} \mathbf{B}_{\mathbf{1}}$ & $\mathbf{A}_{\mathbf{2}} \mathbf{B}_{\mathbf{2}}$ \\
& & \\
\hline L hitung & 0,1618 & 0,1462 \\
& & \\
\hline L tabel & 0,2420 & 0,2420 \\
\hline
\end{tabular}

Keterangan:

$\mathrm{A}_{1} \mathrm{~B}_{1}=$ Metode Penemuan Terbimbing dengan Setting Kooperatif dengan Kemampuan Awal Rendah

$\mathrm{A}_{2} \mathrm{~B}_{2}=$ Metode Konvensional dengan KemampuanAwal Rendah Berdasarkan perhitungan uji normalitas diperoleh bahwa pada kelas eksperimen $\mathrm{L}$ hitung $=0,1618$ dan $\mathrm{L}$ tabel $=$ 0,2420. Jadi L hitung < L tabel, maka dapat disimpulkan data berdistribusi normal. Demikian juga pada kelas kontrol $\mathrm{L}$ hitung $=0,1462$ dan $\mathrm{L}$ tabel $=0,2420$. Jadi $\mathrm{L}$ hitung $<\mathrm{L}$ tabel, maka dapat disimpulkan data berdistribusi normal.

b. Uji Homogenitas

1. Uji homogenitas untuk kelompok data berdasarkan metode pembelajaran 
Tabel: Variansi Kelompok Data Berdasarkan Metode Pembelajaran

\begin{tabular}{ccc}
\hline $\begin{array}{c}\text { Metode } \\
\text { Pembelajaran }\end{array}$ & $\mathbf{n}$ & $\mathbf{S}^{\mathbf{2}}$ \\
\hline $\mathrm{B}_{1}$ & 42 & 358,69 \\
\hline $\mathrm{B}_{2}$ & 39 & 245,15 \\
\hline Jumlah & 81 &
\end{tabular}

Keterangan:

$\mathrm{B}_{1}=$ Metode Penemuan Terbimbing dengan Setting Kooperatif

$\mathrm{B}_{2}=$ Metode Konvensional

$F_{\text {hitung }}=\frac{358,69}{245,15}=1,46$ sedangkan $\mathrm{F}$ tabel dengan taraf nyata $\alpha=0,05$ dan derajat kebebasan $(\mathrm{dk})=(41 ; 38)$ diperoleh $\mathrm{F}_{\text {tabel }}=1,69$. Ini berarti $\mathrm{F}$ hitung lebih kecil dari $F$ tabel, sehingga dapat disimpulkan bahwa kedua kelompok data homogen.

1. Uji homogenitas untuk kelompok data berdasarkan metode pembelajaran dengan kemampuan awal matematika tinggi

Tabel: Variansi Kelompok Data Berdasarkan Kemampuan Awal Tinggi

\begin{tabular}{ccc}
\hline Kelas & $\mathbf{n}$ & $\mathbf{S}^{\mathbf{2}}$ \\
\hline $\mathrm{A}_{1} \mathrm{~B}_{1}$ & 12 & 27,61 \\
\hline $\mathrm{A}_{2} \mathrm{~B}_{2}$ & 12 & 41,61 \\
\hline Jumlah & 24 & \\
\hline
\end{tabular}

Keterangan:

$\mathrm{A}_{1} \mathrm{~B}_{1}=$ Metode Penemuan Terbimbing dengan Setting Kooperatif dengan Kemampuan Awal Tinggi

$\mathrm{A}_{2} \mathrm{~B}_{2}=$ Metode Konvensional dengan KemampuanAwal Tinggi

$$
\text { F hitung }=\frac{41,61}{27,61}=1,51
$$

sedangkan $\mathrm{F}$ tabel dengan taraf nyata $\alpha=0,05$ dan derajat kebebasan $(\mathrm{dk})=$ $(11 ; 11)$ diperoleh $F_{\text {tabel }}=2,85$. Ini berarti $\mathrm{F}$ hitung lebih kecil dari $\mathrm{F}$ tabel, sehingga dapat disimpulkan bahwa kedua kelompok data homogen.

2. Uji homogenitas untuk kelompok data berdasarkan metode pembelajaran dengan kemampuan awal matematika rendah

Tabel 14: Variansi Kelompok Data Berdasarkan Kemampuan Awal Rendah

\begin{tabular}{ccc}
\hline Kelas & $\mathbf{n}$ & $\mathbf{S}^{\mathbf{2}}$ \\
\hline $\mathrm{A}_{1} \mathrm{~B}_{1}$ & 12 & 42,64 \\
\hline $\mathrm{A}_{2} \mathrm{~B}_{2}$ & 12 & 56,02 \\
\hline Jumlah & 24 & \\
\hline
\end{tabular}

Keterangan:

$\mathrm{A}_{1} \mathrm{~B}_{1}=$ Metode Penemuan Terbimbing dengan Setting Kooperatif dengan Kemampuan Awal Rendah

$\mathrm{A}_{2} \mathrm{~B}_{2}=$ Metode Konvensional dengan KemampuanAwal Rendah

Fhitung $=\frac{56,02}{42,64}=1,31$

sedangkan $\mathrm{F}$ tabel dengan taraf nyata $\alpha=0,05$ dan derajat kebebasan $(\mathrm{dk})=$ $(11 ; 11)$ diperoleh $\mathrm{F}_{\text {tabel }}=2,85$. Ini berarti $\mathrm{F}$ hitung lebih kecil dari $\mathrm{F}$ tabel, sehingga dapat disimpulkan bahwa kedua kelompok data homogen.

c. Pengujian Hipotesis

Dalam penelitian ini, hipotesis pertama sampai ketiga diuji dengan menggunakan uji t, sedangkan hipotesis keempat diuji dengan menggunakan ANAVA.

\section{Hipotesis 1}

Harga $t_{\text {hitung dibandingkan dengan }}$ tabel dengan $\mathrm{dk}=\left(\mathrm{n}_{1}+\mathrm{n}_{2}-2\right)=(42$ $+39-2)=79$ pada tingkat kepercayaan $\alpha=0,05$ diperoleh $t_{\text {tabel }}$ $=\mathrm{t}_{(0,95 ; 79)}=1,67$. Dari penelitian didapat $t_{\text {hitung }}=4,36$ maka $t_{\text {hitung }}>$ tabel.

Jadi $\mathrm{H}_{0}$ ditolak, penelitian memberikan hasil yang berarti pada 
taraf nyata $\alpha=0,05$. Jadi dapat disimpulkan bahwa hasil belajar matematika siswa yang diajar dengan menggunakan metode penemuan terbimbing dengan setting kooperatif lebih tinggi dari hasil belajar matematika siswa yang diajar dengan menggunakan metode konvensional.

\section{Hipotesis 2}

Harga $t_{\text {hitung dibandingkan dengan }}$ tabel dengan $\mathrm{dk}=\left(\mathrm{n}_{1}+\mathrm{n}_{2}-2\right)=(12$ $+12-2)=22$ pada tingkat kepercayaan $\alpha=0,05$ diperoleh $\mathrm{t}_{\text {tabel }}$ $=\mathrm{t}_{(0,95 ; 22)}=1,72$. Dari penelitian didapat $\mathrm{t}_{\text {hitung }}=5,39$ maka $\mathrm{t}_{\text {hitung }}>$ $t_{\text {tabel. }}$.

Jadi $\mathrm{H}_{0}$ ditolak, penelitian memberikan hasil yang berarti pada taraf nyata $\alpha=0,05$. Jadi dapat disimpulkan bahwa hasil belajar matematika siswa yang kemampuan awal tinggi yang diajar dengan menggunakan metode penemuan terbimbing dengan setting kooperatif lebih tinggi daripada yang diajar dengan menggunakan metode konvensional.

\section{Hipotesis 3}

Harga thitung dibandingkan dengan tabel dengan $\mathrm{dk}=\left(\mathrm{n}_{1}+\mathrm{n}_{2}-2\right)=(12$ $+12-2)=22$ pada tingkat kepercayaan $\alpha=0,05$ diperoleh $t_{\text {tabel }}$ $=t_{(0,95 ; 22)}=1,72$. Dari penelitian didapat $t_{\text {hitung }}=1,95$ maka $t_{\text {hitung }}>$ $\mathrm{t}_{\text {tabel. }}$

Jadi $\mathrm{H}_{0}$ ditolak, penelitian memberikan hasil yang berarti pada taraf nyata $\alpha=0,05$. Jadi dapat disimpulkan bahwa hasil belajar matematika siswa yang kemampuan awal rendah yang diajar dengan menggunakan metode penemuan terbimbing dengan setting kooperatif lebih tinggi daripada yang diajar dengan menggunakan metode konvensional.

\section{Hipotesis 4 (Analisis Varians/ANAVA)}

Karena $F_{\text {hitung }}=2,77<\mathrm{F}_{\text {tabel }}=4,06$ dengan demikian efek utama interksi faktor kemampuan awal dengan metode penemuan terbimbing dengan setting kooperatif tidak signifikan.

Dari perhitungan dapat disimpulkan bahwa tidak terdapat interaksi antara metode pembelajaran dengan kemampuan awal siswa.

\section{PEMBAHASAN}

Setelah diketahui bahwa kedua kelompok sampel memiliki kemampuan awal yang sama, selanjutnya peneliti melaksanakan proses pembelajaran. Ada dua metode yang digunakan dalam proses pembelajaran yaitu metode penemuan terbimbing dengan setting kooperatif pada kelas eksperimen dan metode konvensional pada kelas kontrol.

Pada akhir pembelajaran seluruh siswa diberi tes akhir dengan tujuan untuk mengetahui kemampuan siswa setelah proses pembelajaran berlangsung. Berdasarkan hasil analisis data yang diperoleh melalui pengujian hipotesis, terlihat hipotesis 1, 2, dan 3 yang diajukan $\mathrm{H}_{0}$ nya ditolak. Ini berarti $\mathrm{H}_{1}$ diterima. Sedangkan hipotesis 4 terjadi sebaliknya yaitu $\mathrm{H}_{0}$ diterima pada taraf nyata $\alpha=0,05$, berarti $\mathrm{H}_{1}$ yang ditolak. Penyebab diterima atau ditolaknya $\mathrm{H}_{1}$ dapat dijelaskan sebagai berikut:

Pada pengujian hipotesis pertama bahwa hasil belajar matematika siswa yang diajar dengan menggunakan metode penemuan terbimbing dengan setting kooperatif lebih tinggi dari pada yang diajar dengan menggunakan metode konvensional, dikarenakan siswa mengerti apa arti belajar, apa manfaatnya dan bagaimana mencapainya. Dalam metode penemuan terbimbing dengan setting kooperatif ini menuntut siswa lebih aktif terlibat dalam proses 
pembelajaran. Hal ini akan membuat siswa terbiasa mengaktifkan pengetahuan dan keterampilan yang sudah ada. Pemahaman konsep didapatkan siswa melalui kegiatan-kegiatan yang telah dirancang dalam LKS.

Pengujian hipotesis kedua bahwa hasil belajar matematika siswa yang kemampuan awal tinggi yang diajar dengan metode penemuan terbimbing dengan setting kooperatif lebih tinggi dari pada yang diajar dengan metode konvensional. Hal ini siswa yang memiliki kemampuan awal tinggi akan lebih mendorong bagi peningkatan hasil belajar matematika. Peningkatan hasil belajar ini akan lebih nyata dengan diterapkannya metode penemuan terbimbing dengan setting kooperatif dengan menggunakan lembar kerja siswa yang disediakan. Siswa yang mempunyai kemampuan awal tinggi dapat denga mudah menghubungkan konsep yang akan ditemukan dengan kemampuan yang telah dimiliki.

Pengujian hipotesis ketiga bahwa hasil belajar matematika siswa yang kemampuan awal rendah yang diajar dengan metode penemuan terbimbing dengan setting kooperatif lebih tinggi dari pada yang diajar dengan metode konvensional. Pada penelitian ini siswa yang memiliki kemampuan awal rendah pada umumnya merasa kesulitan untuk menenmukan konsep pada masalah yang diberikan, mereka sangat tergantung pada bimbingan guru dan teman sekelompoknya, bahkan ada juga yang pasif hanya memperhatikan temannya bekerja. Kesulitan utama yang dihadapi siswa yang berkemampuan awal rendah adalah siswa kurang mampu memahami keterkaitan antara beberapa konsep. Kondisi ini akan lebih parah bagi siswa yang memiliki kemampuan awal rendah pada metode konvensional, mereka akan lebih cenderung untuk menghindar dari pembelajaran yang sedang berlangsung.
Pengujian hipotesis keempat tidak terdapat interaksi. Interaksi merupakan adanya efek perlakuan atau adanya kerjasama dua variabel bebas atau lebih yang mempengaruhi satu variabel. Artinya perbedaan selisih hasil belajar matematika yang diajar dengan metode penemuan terbimbing dengan setting kooperatif dan yang diajar dengan metode konvensional tidak mempunyai beda yang signifikan secara perhitungan statistika antara siswa yang memiliki kemampuan awal tinggi dan rendah. Hal ini menunjukkan bahwa faktor kemampuan awal tidak tergantung pada metode pembelajaran atau sebaliknya dalam mempengaruhi hasil belajar siswa.

Jadi dapat disimpulkan bahwa peningkatan kemampuan matematika siswa yang pembelajarannya menggunakan metode penemuan terbimbing dengan setting kooperatif lebih tinggi dari pada peningkatan kemampuan matematika siswa yang pembelajarannya dengan menggunakan metode konvensional.

\section{PENUTUP}

Berdasarkan hasil penelitian yang telah dikemukakan pada BAB IV dapat disimpulkan:

1. Hasil belajar matematika siswa yang diajar dengan menggunakan metode penemuan terbimbing dengan setting kooperatif lebih tinggi dari pada yang diajar dengan metode konvensional.

2. Hasil belajar matematika siswa yang memiliki kemampuan awal tinggi yang diajar dengan metode penemuan terbimbing dengan setting kooperatif lebih tinggi dari pada yang diajar dengan metode konvensional.

3. Hasil belajar matematika siswa yang memiliki kemampuan awal rendah yang diajar dengan metode penemuan terbimbing dengan setting kooperatif lebih tinggi dari pada yang diajar dengan metode konvensional. 
4. Tidak terdapat interaksi antara metode pembelajaran dan tingkat kemampuan awal matematika dalam

mempengaruhi hasil belajar matematika siswa.

\section{DAFTAR RUJUKAN}

Ahmad Rohani, Abu Ahmadi. 1991. Pengelolaan Pengajaran. Jakarta: Rineka Cipta.

Aleks Maryunis. 1989. Metode Pemetaan Informasi dalam Proses Belajar Mengajar Matematika di SMA. Jakarta: Disertasi FPS IKIP. . 2003. Upaya Peningkatan Hasil Belajar Matematika Siswa SLTP Menggunakan Strategi Pemetaan Informasi. Forum Pendidikan, 28(3): 235-336.

Depdiknas. 2004. Materi Pelatihan Terintegrasi Berbasis Kompetensi Mata Pelajaran Matematika. Buku 1-3. Jakarta: Depdiknas.Sujono. 1988. Pengajaran Matematika Untuk Sekolah Menengah. Jakarta: Depdikbud.

Djarwanto. (2002). Statistik Non Parametrik. Jakarta: Inova.

Erman Suherman. 2003. Strategi Belajar Mengajar Kontemporer. Bandung: FMIPA UPI.

Herman Hudojo. 1983. Teori Dasar Belajar Matematika. Jakarta: Dirjen Dikti - P2LPTK. .1984. Metode Mengajar Matematika. Jakarta: Depdikbud Dirjen Dikti. . 1998. Pembelajaran Matematika Menurut Pandangan Konstruktivistik. Makalah disajikan pada Seminar Nasional "Upaya-upaya Meningkatkan Peran Pendidikan Matematika dalam Era Globalisasi". Program Pascasarjana IKIP Malang: 4 April.

Kamus Besar Bahasa Indonesia. 1995. Balai Pustaka.

Muhibbin Syah. 2003. Psikologi Belajar. Jakarta: P.T. Raja Grafindo Persada.

Muliyardi. 2003. Ketika Seni Bercumbu dengan Matematika. Makalah disajikan pada Seminar Nasional Difusi Inovasi dalam Pembelajaran Matematika di UNP tanggal 6 September 2003.

Nana Sudjana. 1989. Strategi Belajar Mengajar Matematika. Bandung: Tarsito.

.2001. Penilaian Hasil Proses Belajar Mengajar. Bandung: P.T Remaja Rosdakarya.

Paulina Panen. 2003. Belajar dan Pembelajaran I. Jakarta: Pusat Penerbitan UT.

Pratiknyo Prawironegoro. 1985. Evaluasi Hasil Belajar Khusus Analisis Bidang Studi Matematika. Jakarta: P2LPTK.

Ratna Wilis Dahar. 1989. Teori-teori Belajar. Jakarta: Erlangga.

Roestiyah, N. K. 1989. Dikdaktik Metodik. Jakarta: Bina Aksara.

Ruseffendi, E. T. 1988. Pengajaran Matematika Meningkatkan CBSA. Bandung: Tarsito. . 1991. Pengantar Kepada Membantu Guru Mengembangkan Kompetensinya dalam Pengajaran Matematika Untuk Meningkatkan CBSA. Bandung: Tarsito. 1988. Mengajar Belajar Matematika. Jakarta: Depdikbud LPTK. 
Sadirman A.M. 2007. Interaksi dan Motivasi Belajar Mengajar. Jakarta: P.T Raja Grafindo Persada.

Slameto. 1988. Evaluasi Pendidikan. Jakarta: Bina Aksara.

Slavin. 1995. Cooperatif Learning; Theory, Resarch and Practice. Allyn and Bacon: Boston.

Suharsimi Arikunto. 2003. Dasar-dasar Evaluasi Pendidikan. Jakarta: Bumi Aksara. 2003b. Manajemen Penelitian. Jakarta: Roneka Cipta.

Syaiful Sagala. 2003. Konsep dan Makna Pembelajaran. Bandung: Alfabeta.

Winarno Surakhmad. 1990. Pengantar Interaksi Belajar Mengajar, Dasar dan Teknik Metodologi Pengajaran. Bandung: Tarsito.

W. S. Winkel. 1989. Psikologi Pengajaran. Jakarta: Gramedia. 